\title{
De Bataille a Fogwill (o de la imaginación sadiana a la experiencia dictatorial)
}

2. Silvia Schwarzböck / Universidad de Buenos Aires / defilo@filo.uba.ar

\section{Resumen}

Este trabajo se propone analizar cómo la tesis de Fogwill sobre la experiencia de la última dictadura argentina («Los vencedores callan ... Los perdedores piensan, narran») reformula la tesis de Bataille sobre la imaginación sadiana («Los civilizados hablan, los bárbaros se callan»).

Si bien Fogwill no ha desarrollado, explícitamente, una teoría estético-política sobre la última dictadura argentina, este trabajo intenta reconstruirla a partir de sus artículos periodísticos (recopilados como Los libros de la guerra) y de las ideas de dos de sus novelas (Vivir afuera y Nuestro modo de vida).

Palabras clave: Fogwil $•$ última dictadura argentina • Bataille $\cdot$ imaginación sadiana

\section{Abstract}

This work proposes to analyze how Fogwill's thesis about the experience of the last Argentinean dictatorship («The winners keep silent. (...) The losers think, narrate») reformulates Bataille's thesis about Sade's imagination («The civilized persons talk, the barbarians keep silent»).

Although Fogwill hasn't explicitly developed an aesthetical-political theory about the last dictatorship in Argentina, such theory could be sketched in the opinions of many of his journalistic articles (collected as Los libros de la Gue$\mathrm{rra}$ ) and in the ideas of two of his novels (Vivir afuera and Nuestro modo de vida).

Key words: Fogwill • last Argentinean dictatorship · Bataille $\cdot$ Sade's imagination 
Los civilizados hablan, los bárbaros se callan (...) La violencia es silenciosa.

Georges Bataille (1957:192)

Los vencedores callan. (...) Los perdedores piensan, narran. (...) Es que el orden social no necesita entender, sólo precisa hacerse entender.

FOGWILL (2008a:84)

\section{Introducción}

Los verdugos callan, sostiene Bataille. Quedan, por eso, del lado de la barbarie. Quien los imagina hablando sobre su poder — como hace Sade — está del lado de las víctimas, que es el lado de la civilización. En el mundo empírico, personajes como los de Sade — sujetos poderosos, que gozan de impunidad-— se habrían mantenido callados, incluso entre pares.

Lo que Bataille sostiene de la imaginación sadiana (que hace entrar en la conciencia lo que es contrario a ella: la violencia silenciosa, y que, al hacerlo, Sade revela su posición de víctima, no de verdugo), Fogwill lo dice, a su modo, de la última dictadura argentina: son los vencidos los que hablan de ella (los que la piensan y la narran), mientras los vencedores callan.

Sólo que, al adjudicarle a los vencedores (y no a los verdugos) la acción de callar, Fogwill trastoca, radicalmente, los conceptos con que Bataille piensa a Sade: la experiencia dictatorial argentina — deja sobreentender — no puede leerse desde la imaginación sadiana.

Los vencedores, demuestra la experiencia argentina, no son los verdugos (los represores), sino el poder económico que los instrumentó; su victoria, por tener que permanecer callada, es una victoria-derrota. Los vencidos, mientras tanto, al no poder sino pensar y narrar otra cosa que su derrota, la convierten en una derrota-victoria.

La paradoja de esta derrota-victoria, según Fogwill, es que «los registros de la derrota y las evocaciones de las derrotas son parte de un aparato involuntario de celebración de las victorias, especialmente cuando no hay obras de celebración de la victoria porque los victoriosos necesitan hacerla pasar como una derrota» (2008a:82).

En lugar de pensar lo impensable identificándose con la mente del verdugo (el mérito filosófico de Sade, leído por Bataille) o de convertirlo en el programa de vanguardia de un ateísmo consecuente y radical (el mérito literario de Sade, leído por Le Brun), Fogwill lo trata, al pensarlo, como el pensamiento de aquel que no piensa. La pregunta por lo impensable, formulada por él, es la pregunta por qué piensan los que no piensan. ¿Cómo es no pensar, cuando el que no piensa es un ex agente de inteligencia de la dictadura, reciclado en la democracia como importador de tecnología militar (el personaje de Wolff en Vivir afuera), o un ejecutivo de una multinacional que hace negocios con la uRss en la Argentina de 1980 (el personaje de Fernando Romero en Nuestro modo de vida)? 


\section{Si los verdugos hablaran. Sade según Bataille}

Bataille insiste en que el discurso de Sade es el discurso de una víctima, no el de un verdugo. Un verdugo no se dirige al público: sólo habla con sus pares, si es que los trata. Y cuando los trata, el lenguaje con que les habla es el lenguaje del Estado, es decir, el lenguaje del poder que lo justifica (1957:194).

Sade, en cambio, habla. Y habla haciendo hablar, hasta la saturación, a personajes que, de haber existido, habrían callado. La imaginación sadiana, de acuerdo con la tesis de Bataille, es la de un hombre castigado. Sólo un hombre castigado - como lo fue Sade buena parte de su vida, mientras estuvo en prisión— imagina cuál sería el discurso de sus verdugos, si sus verdugos hablaran.

Pero para que los personajes de Sade estén escritos desde ese punto de vista (el punto de vista de un hombre castigado), algo de la violencia extraliteraria (la violencia silenciosa) tiene que escapárseles. La violencia silenciosa, imaginada por un hombre castigado, entra en el lenguaje con la calma de la razón. Por medio del lenguaje sadiano —el que Sade le hace hablar a personajes que, de existir, no hablarían de lo que hacen - entra en la conciencia, para el lector, lo que subleva a la conciencia.

Pero, al hacer esta operación, propia de un autor ilustrado, Sade construye una violencia ficticia, una violencia por la cual sus lectores - $\mathrm{e}$ incluso sus no lectores: quienes saben de la existencia de la obra de Sade, pero no la leen- pueden tomar, progresivamente, conciencia de sí mismos. La prueba de esta contribución —indica Bataille— es el término sádico (1957:I89).

En sus tesis sobre Sade, Bataille vuelve, una vez más, a la dialéctica del amo y el esclavo, que para él -igual que para todos los filósofos franceses pre-posestructuralistas - es una teoría de Kojève, no una figura clave — leída por Marx como la lucha de clases- de la Fenomenología del espiritu de Hegel.

Hegel enseña, con esta figura, que así como el amo no puede experimentar, en carne propia, el deseo de emancipación del esclavo, el esclavo no puede imaginar, cuando se pone en el lugar del amo, en qué consiste el mutismo de la violencia. No obstante, hay algo que entiende el que no tiene el poder, que no puede entenderlo quien lo tiene, desde el sometimiento hasta el deseo de emancipación, sólo que, para entenderlo, tiene que ponerse en otra posición que la que ocupa en la sociedad, como si se tratara de una comedia. El problema de este juego, leído desde la óptica de Bataille, es que es, precisamente, un juego.

Así como la dialéctica hegeliana, en el capítulo sobre el señor y el siervo (que Kojève convierte, para su respectivo siglo, en la dialéctica del amo y el esclavo), está escrita en clave de comedia (termina, de hecho, con el triunfo del esclavo, que logra, paradójicamente, la imposición general del trabajo), las novelas de Sade terminan estando escritas, a no tan largo plazo, para lectores que no se escandalizan con ellas.

Bataille, por eso, escribe su prólogo a La Nouvelle Justine (titulado «Sade y el hombre normal») desde el punto de vista de un lector —un hipotético lectoral que Sade todavía escandaliza: quienes escriben sobre él desde la admiración 
—advierte- edulcoran su pensamiento. Si los admiradores de Sade fueran consecuentes con el pensamiento sadiano, deberían estar presos. Si no lo están, es porque admirar la construcción de un hombre soberano dentro de los límites de la literatura - en el siglo xx — no es algo que tenga la menor consecuencia.

La soberanía, en el siglo xx, no se busca por la vía de la admiración de los hombres soberanos (qué fueron los príncipes, qué fue la aristocracia, al hombre del siglo xx le resulta inaccesible), sino por la vía de la revuelta. Por la revuelta, Bataille reconoce que todo hombre sigue siendo, en potencia, un ser soberano, sólo que lo sigue siendo «a condición de que prefiera morir antes que ser sojuzgado» (I988:232).

Si Bataille pone una condición tan alta para que un hombre de su siglo merezca el nombre de soberano, es porque su hegelianidad, aun siendo kojeviana, no le permite suponer sino lo que imagina (porque la dialéctica hegeliana no argumenta ni demuestra: imagina) la dialéctica del amo y el esclavo: que los hombres, puestos ante la disyuntiva de trabajar (es decir, ser sojuzgados) o morir, siempre prefieren (y van a seguir prefiriendo) trabajar.

$\mathrm{Al}$ hombre que trabaja le resulta inimaginable qué pueda ser un hombre soberano. Dado que sabe que hubo hombres soberanos (los príncipes o soberanos en sentido antiguo), puede advertir que los personajes de Sade hablan - y se comportan - como si lo fueran (aunque reconozca que, si lo fueran al exterior de la ficción, no hablarían de ello). Lo que no puede - y lo mismo le sucede al propio Sade - es imaginárselos de otra manera que como como asesinos seriales impunes, como sujetos que, por ser poderosos, están eximidos de rendir cuentas por sus actos (quien los exime de rendirlas es el Estado, que fue instituido por ellos para protegerse de la revuelta).

Bajo estas circunstancias, con la única forma de soberanía con que el hombre que trabaja puede comparar la soberanía principesca, que le resulta inimaginable, es con la revuelta. No importa que, en la comparación, lo que advierta sea, sobre todo, la inconmensurabilidad. Bataille trata a Sade como un teórico del hombre soberano, no como si hubiera sido el hombre soberano que todo hombre, gracias a la revuelta, podría llegar a ser.

Es por eso que Bataille recomienda hablar de Sade desde un punto de vista contrario al suyo, desde el punto de vista de aquel que, al leerlo, reacciona como si viera en él al asesino de su hija (1957:184). No obstante, cinco páginas más adelante - como haría cualquier dialéctico- dice lo contrario: ese punto de vista ya no existe, se ha modificado para siempre. Que se hable de sadismo hace que Sade quede del lado de la razón, de las personas razonables que son sus lectores. A través de su lectura, la razón (de los lectores) se ilustra a sí misma.

$\mathrm{Al}$ hacer entrar a la violencia silenciosa en el discurso de la razón (y, por ende, en el mundo civilizado de la lectura), Sade termina ilustrando a sus lectores sobre su propia violencia silenciosa. No importa que sea un ilustrado oscuro como lo llamaron Horkheimer y Adorno, para ponerlo en dialéctica con Kant (IO2-I47) — si él es (todavía) un ilustrado. La humanidad podría llegar a ser menos silenciosamente violenta — más civilizada— gracias a Sade. 
Contra la domesticación de Sade, Bataille se propone conseguir, en el Prólogo de El erotismo, un punto de vista que no lo admire, que no lo ponga como la cumbre insuperable de la audacia intelectual, pero, sobre todo, que permita relacionarlo con su opuesto: «lo he sacrificado todo a la búsqueda de un punto de vista desde el cual sobresalga la unidad del espíritu humano (...) desde la santa hasta el voluptuoso» (I957:II-I2). Ese punto de vista es el de la experiencia interior: la experiencia religiosa y la experiencia erótica.

Frente a un autor como Sade, que quiere escribir desde el punto de vista de los verdugos (por lo cual es un hombre castigado: si fuera realmente un verdugo, no escribiría), quien quiera escribir sobre él sin edulcorarlo — como quiere Bataille- tiene que evitar la identificación.

Si Sade es radicalmente ateo, si satura al lector con demostraciones de la inexistencia de Dios, si practica una negación infinita que se vuelve contra el propio sujeto de la negación (porque el verdugo tiene que aceptar ser él mismo también negado, para que el crimen, como objeto, devenga sujeto: todo verdugo es una potencial víctima de otro verdugo), la estrategia de Bataille, para no edulcorarlo, es pensarlo desde un punto de vista anti-ateo. Sólo que ese punto de vista, que relaciona al voluptuoso con la santa, no lo proveen ni las religiones ya existentes ni las voluptuosidades ya conocidas. Es el punto de vista de una «experiencia solitaria, sin tradición, sin rito y sin nada que me guíe; pero sin nada que me estorbe tampoco» (38).

El punto de vista contrario al de Bataille - y contra el que Bataille construye el suyo - es el punto de vista ateo, para el cual Sade sería, invariablemente, el primero en entender no la muerte de Dios (Dios como algo finito, Dios como algo que los hombres primero crean y después matan), sino la inexistencia de Dios (Dios como aquello sin lo cual todo estaría permitido).

\section{El infinito ateo: Sade según Le Brun}

Los ateos tienden a repetir. Y a repetirse. La atea Annie Le Brun, en la "Advertencia» de No se encadena a los volcanes, le dice al lector, orgullosa, que en la edición de sus conferencias, que hacen de capítulos del libro, no ha eliminado las repeticiones: de una a otra conferencia repite, programáticamente, las mismas citas y las mismas tesis sobre Sade. Su ateísmo - parece dar a entender - la hace monotemática: «no me cansaré jamás de repetir: "Dios es el único error que no puedo perdonarle al hombre”» (2I).

A Le Brun le pasaría, como atea, lo mismo que, según ella, le pasa a Sade: todo necesita recomenzar, como una gimnasia, también la demostración de la inexistencia de Dios. Refutando de todas las maneras posibles la idea de una causa primera (un ejercicio repetitivo, al que lo llama el ateísmo entendido literalmente y en todos los sentidos), Sade descubriría, finalmente, el infinito con el que su mente debe medirse.

El infinito que Le Brun le atribuye a Sade es, ante todo, un infinito no romántico. Pero no por eso ese infinito es ilustrado: los ilustrados eran deístas, no ateos, igual que los revolucionarios de $\mathrm{I} 789$. El infinito sadiano, como infinito no 
romántico y no ilustrado, es un infinito ateo, un infinito que no hace escuela, que no tiene precedentes ni sucesores.

Este infinito ateo, si se tradujera a términos científicos (algo que a Le Brun le interesa muy poco), equivaldría al infinito de la física clásica, el del movimiento rectilíneo uniforme, el que alcanzaría un cuerpo al que, en un espacio vacío, se lo dejara desplazarse sin obstáculos ni rozamientos.

Así se desplazan, de hecho, los cuerpos de los amos - como verdaderos señores del mundo de la Fenomenología hegeliana- en el hipotético castillo de Silling de Las I2o jornadas de Sodoma. Por esta razón, Le Brun llama a este libro «una obra única» (70) o también «el texto más intolerable que pueda haber» (49). Todo lo que hace de Sade un autor excepcional, según ella, es algo que él ha hecho por primera vez, aunque, por eso mismo, no pueda ser la última: los ateos (se) repiten ad infinitum.

Si Las I2o jornadas de Sodoma son lo que Le Brun dice que son —una obra única, el texto más intolerable que pueda haber-, ella se autoproclama, consecuentemente, como la única (o la primera) en notarlo. La primera vez de Sade es, en realidad, su primera vez. Lo que hace única (o primera) a una obra como Las I20 jornadas de Sodoma sólo está en condiciones de entenderlo alguien como ella, tan atea como Sade.

\section{Los anticristos: Nietzsche contra Sade y Le Brun contra sí misma}

Este modo de hablar que tiene Le Brun, por el cual logra una identificación tan completa con Sade (ella es él y él es ella), no sólo le daría la razón a Bataille, cuando dice: "si admiramos a Sade, edulcoramos su pensamiento» (I957:185), sino también a Nietzsche, cuando, en la «Ley contra el cristianismo», con que cierra El Anticristo, advierte hasta qué punto todo lo que él aborrece de la moral cristiana (aquello que la convierte en una antinaturaleza) está mejor desarrollado en las personas que no creen en Dios (pero sí en la ciencia) que en las que creen en él. Por eso hay que castigarlo más en los protestantes que en los católicos, en los protestantes liberales que en los protestantes ortodoxos, en los pastores que en los sacerdotes, y en los filósofos que en los pastores (III).

Es la moral cristiana, en la medida en que se seculariza, la que engendra criminalidad, vileza o deseo de hacer el mal, no la naturaleza o la razón. Lo pervertido, para Nietzsche, es negar la naturaleza.

Si se pone a Le Brun contra sí misma — si se le exige a su pensamiento que sea consecuente con sus propias tesis - ella debería decir de Marx, en realidad, lo que dice de Sade: pensar a los hombres, una vez liberados de Dios, actuando contra sí mismos, contra su propio egoísmo, es radicalmente más osado que pensarlos haciendo como ateos, de manera consecuente, lo mismo que los poderosos hacen, de manera inconsecuente, sin dejar de ser cristianos.

El surrealismo de Le Brun, al querer salvar a los hombres de un Dios que ellos mismos se han inventado para salvarse, se convierte en un humanismo. El Dios que los hombres se inventaron, por inventárselo a su medida, como piadoso con 
los pecadores y necesitado de ellos para ser Dios, nunca logró impedirles hacer el mal, mucho menos a quienes estaban en posición de quedar impunes ante los hombres (no ante Él).

Para hacer de Sade el autor más osado que haya existido, Le Brun elogia en él una tesis que, antes, ha tenido el cuidado de hacer suya: la razón estaría ligada, orgánicamente, a la ferocidad del deseo. Ahora bien: los ejemplos que podrían darse de esta ferocidad, cuando opera en el mundo real (no en el mundo hipotético del castillo de Silling, es decir, en el espacio vacío del movimiento rectilíneo uniforme, sin rozamiento ni obstáculos), son ejemplos de deseos feroces ya cumplidos por la humanidad: encierro, explotación, humillación, sometimiento, tortura y exterminio.

No se entiende, al leer a Le Brun, por qué los hombres necesitarían ser ateos, en lugar de simplemente aristócratas — como diría Nietzsche-, para ser tan libres como los libertinos sadianos y poder cometer, así, los mismos crímenes que ya cometieron $-\mathrm{y}$ siguen cometiendo- otros hombres que, por su posición social y sus vínculos con el Estado, gozan de impunidad.

Nietzsche aborrece a Dios, como invención humana, tanto como Sade. Pero él advierte que sus sustitutos, los diosecillos (el Estado, la Moral, la Justicia, la Igualdad) se internalizan en los hombres — sobre todo en los ateos- de una manera más perversa (más contranatural, más contraria a la vida) que el Dios Absoluto que vienen a reemplazar.

Que al hombre sólo le inspire respeto aquello de lo que teme represalias materiales — sea humano, inhumano, o sobrehumano — indica que ya sabe, por su propia experiencia, que son siempre otros hombres, con más poder que él, sus verdugos más próximos. La vida de los ateos, gracias a esta sabiduría atroz, no es más feliz que la de los creyentes, incluso cuando se organicen junto a otros hombres, con mayor o menor éxito, para cambiar las relaciones de poder.

\section{Materialismo de salón}

La trampa en la que cae Le Brun, producida por su propia admiración por Sade (sumada al su entusiasmo desmesurado por el interés que él tenía por el teatro), es la de tomar el pensamiento sadiano, para justificar esa admiración, como un pensamiento consecuente. Así, para ella, «Las I2o jornadas de Sodoma constituyen la primera visión materialista consecuente, que llega a verificar el pensamiento del cual proviene con lo que se supone le es más ajeno" (85).

El método crítico sadiano, para ser consecuente con su programa y poner sus ideas en escena (como un modo de verificarlas), consistiría en tomar cada una de esas ideas «literalmente y en todos los sentidos», a fin de brindarle todas las oportunidades para que logre $-\mathrm{o}$ no- encarnarse (86). El pensamiento encarnado - para Le Brun igual que para Sade - es el teatro. La teatralización es materialización y la materialización, verificación.

De la posibilidad de que un pensamiento se encarne — de la posibilidad de evaluar esa posibilidad poniéndola en escena- dependería la libertad de pensar. 
Si Le Brun tiene razón —o Sade, que para el caso es lo mismo, por la identificación total que ella tiene con él—, todo pensamiento libre (o librepensamiento) es pensamiento ilustrado. Bajo este criterio, el ilustrado oscuro es Kant, no Sade.

La no necesidad de que el filósofo se represente lo que piensa es, en gran medida, lo que le permite ser inconsecuente consigo mismo. Fichte dice que Kant no es consecuente con su idealismo: un yo que pone al no yo - un yo absoluto- no puede obligarse, después de ese acto, a ceñir su conocimiento a los límites de la ciencia. ¿De dónde sale la incognoscibilidad de la cosa en sí sino de la inconsecuencia kantiana que destaca Fichte, del reconocimiento de que la razón filosófica no puede atarse todo el tiempo a la ciencia, por más que lo quiera, porque está atada, antes que a ella, a un deseo ilimitado (el de conocer la cosa en sí, el objeto fuera de los límites de la construcción que hace de él el sujeto), algo que la condena, irremediablemente, a la metafísica? Sólo la ciencia, en la medida en que no desea conocer nada que exceda la empiria, podría ser consecuente consigo misma, un saber sin autocontradicciones, sin paradojas.

En una historia de la filosofía escrita desde el materialismo, Sade tendrá que incorporarse a ella como alguien que ha hecho otra cosa que lo que Le Brun le elogia (el ser consecuente, por primera vez, con las exigencias de la razón).

Esa otra cosa que haber escrito por primera vez desde una ilustración consecuente podría ser haber pensado (haberse atrevido a pensar, cumpliendo el lema de la ilustración) desde el punto de vista de lo impensable. Nadie puede pensar desde el punto de vista de lo impensable — sostiene Bataille — si antes no ha dominado, dentro de sí, aquello que lo aterroriza. Pero, para dominarlo, tiene que mirarlo de frente. La pregunta que se hace el lector de Bataille, entonces, es qué aterrorizaba a Sade ¿Ser — como era- una víctima que intentaba escribir lo que pensaría un verdugo?

\section{El silencio de Sade}

Si el verdugo no habla sino entre pares y, al hacerlo, usa la lengua que lo absuelve - la lengua del Estado-, la verborragia de los personajes de Sade tiene que articularse, para no ser una mera parodia, en el modo de una ficción teórica: es una construcción hecha para un lector que está siendo enseñado. Los conceptos necesitan de puesta en escena, de teatralidad, porque, como sucede en una clase (o en un capítulo de un libro de filosofía) alguien está escuchando (o leyendo). La imaginación sadiana es una imaginación teorética.

Sin embargo, a diferencia de los filósofos que exponen su sistema desde el punto de vista de lo Absoluto (como Schelling y Hegel), Sade no le pide al lector que se identifique con él, en la medida en que él, como filósofo, no está puesto en el lugar de lo Absoluto: si lo estuviera, la víctima debería formar parte, con su propio discurso, del sistema en el que el verdugo la niega (y la aniquila). Quien lee a Sade debe quedar en un lugar incómodo, que le exige preguntarse, continuamente, por su punto de vista como lector. Y por lo que el autor calla, más allá de lo que les hace decir a sus personajes. 
Contra lo que sostiene Le Brun, al insistir en que, para Sade, «la filosofía debe decirlo todo o no decir nada» (85), la filosofía sadiana, a pesar de la verborragia de sus personajes, calla más de lo que dice. La libertad negativa, el derecho de hacer todo lo que no está prohibido por la ley, convierte al saber sobre el nacimiento del Estado en un secreto de Estado: si nada había obligado a los poderosos (a los que no tenían nada que temer) a entrar en un pacto en el que todos se obligaban a deponer la fuerza que habían acumulado en base al engaño, eran ellos mismos, entonces, quienes lo habían convocado para no perderla. Ese saber, del que nace la diferencia entre los que mandan y los que obedecen, es el que callan los personajes de Sade. Un ejemplo claro de ese silencio es el inicio de la historia de Juliette.

Mme. Delbène, la madre superiora del convento al que Juliette ingresa a los I3 ańos, acepta la presencia de la moralidad - la acepta como un credo contra natura-, a la vez que la repudia por ser inútil: no sirve para frenar una mala acción ni para castigarla, sólo sirve para martirizar al que la comete. De lo que se trata, si se quiere evitar la tortura de la conciencia - el remordimiento-, es de tomar prevenciones, cuando se comete una mala acción, para no ser sorprendido. Porque el remordimiento aparece cuando se es atrapado, no cuando la acción queda impune. El dolor proviene de haber sido descubierto. Cuando la acción se repite muchas veces sin que su autor sea atrapado, el remordimiento desaparece. Pasado cierto umbral, la acción mala no puede dejar de hacerse y la tortura de la conciencia, que debería acompañarla, no vuelve a hacerse sentir.

Pero la repetición de malas acciones, por sí sola —-se da cuenta Juliette—, no alcanza para convertirse en libertina. No basta con desatender las enseńanzas morales. Esa desatención podría deberse a la falta de carácter. Tampoco parece un buen argumento mencionar la paradoja de la naturaleza, que gusta de ser violentada, porque cada vez que alguien la vence, queda más encadenado a ella. Si así fuera, la vida libertina sería, simplemente, un comportamiento antisocial que queda impune. $\mathrm{O}$ una forma de fanatismo antirreligioso, que es como lo propagandiza Mme. Delbène entre las novicias. Por eso no convence a Juliette: para ser libertina — se da cuenta ella - hace falta endurecerse tanto como para ser una santa.

Cuando Juliette le pregunta a Delbène cómo ha hecho para endurecerse, ella le dice que tiene que esperar a que tengan más confianza como para que le confíe su secreto. La superiora esconde el dato más relevante de su programa de iniciación. Juliette, de todos modos, va a aprenderlo sola, con la traición de Dorval. Lo que endurece es el sufrimiento. Pero no el sufrimiento que promueven los teóricos de la virtud, empezando por Aristóteles. Ese sufrimiento es el sufrimiento de ser castigado. El peor sufrimiento — piensa Juliette - no es el del castigo que depara la ley (moral o jurídica), sino el de saberse víctima de la astucia ajena. La traición, el engaño, la estafa, el robo, generan en la víctima no sólo el deseo de venganza (porque la venganza, con ciertos aditamentos, puede trocarse en justicia), sino el deseo de cometer uno mismo esas acciones. Es la identificación con el opresor lo que se aprende siendo víctima. 


\section{Los ilustrados oscuros}

Según Arendt, nunca hubo una burguesía ni un soberano capaces de adoptar la filosofía hobbesiana (203). Hobbes es, para Arendt, lo mismo que Sade para Horkheimer y Adorno: un teórico de la burguesía en el que la burguesía no se atreve a leerse. En este punto, los tres tienen razón. La burguesía gusta leerse en Kant, el teórico de los límites que ella, en tanto racional, debería autoimponerse.

Quien hizo notar este rasgo hipócrita de la burguesía fue Horkheimer (I-8I). Los impulsos egoístas — dice — son tan condenables para la teoría como irresistibles para la praxis. Nadie cuestiona que desarrollarlos, para la subsistencia, sea necesario, pero dentro de una teoría sólo pueden ser tolerados - dado que, entre los lectores, están quienes más paradigmáticamente los encarnan—, si la teoría demuestra que por ellos, a largo plazo, se llega a la concordia y la sociabilidad. La proclamación abierta del egoísmo siempre fue mal recibida por quienes mejor la encarnaban. Los primeros en comprobarlo fueron Mandeville y Sade.

Sade escribe en una época donde ya opera la mala conciencia de la ilustración, a la cual podría estar contribuyendo sacrificándose a ser censurado. Por lo mismo que Kant tiene nostalgia del futuro, los burgueses, un día no tan lejano, tendrán miedo. No se puede universalizar el principio de la vida libertina, si ese principio es la impunidad.

Mme. Delbène se pregunta, frente a Juliette, por qué la promesa de la vida eterna, que tranquiliza a "algunos imbéciles desgraciados», a los que se les niega la felicidad en la tierra, necesitaría ser creída por millones de personas, al margen de su suerte terrenal. Liberarse del temor al castigo eterno — sostiene- es mil veces más agradable que imaginar lo que se recibiría, recién después de la muerte, a cambio de vivir pensando en él. Las religiones — razona - evitan la degradación de las costumbres: por eso el Estado las promueve entre sus súbditos. Ahora bien, los frenos que sirven para mantener a raya a las clases populares - concluye - no tienen ninguna validez en los libros de filosofía. Los filósofos saben — presume ella- que nada ha sido prohibido por la naturaleza.

Mme. Delbène piensa al filósofo, en sentido moderno, como alguien que interpreta la naturaleza. Poniéndose en el lugar de filósofa, rechaza la máxima cristiana «no hacer a otros lo que no se quiere que le hagan a uno» para seguir el único precepto que, según ella, ha dictado la naturaleza: «deleitarnos, no importa a costa de quién». ¿Cómo garantizarse, si este principio se generalizara, no ser la futura víctima de cualquier prójimo? Cuando Juliette se lo pregunta (y se lo pregunta de manera personal: ¿qué pasaría si fuera ella la desgraciada?), la superiora contesta que sabría sufrir sin quejarse: "Cuando permito que los otros sufran, sin socorrerlos, es porque yo he aprendido a sufrir, a mi vez, sin ser socorrida (...) Quien sepa endurecerse ante los males del otro se vuelve pronto impasible a los suyos propios» (Sade:II4).

$\mathrm{Al}$ razonar así, sin importarle que la máxima de la vida libertina (gozar a expensas de todos los otros seres humanos) no pueda universalizarse sin que se vuelva autocontradictoria (porque para gozar a expensas de todos los otros seres humanos 
es necesario que no todos los otros seres humanos se propongan el mismo fin), Mme. Delbène demuestra, ante Juliette, que no le importa la extinción del género humano, que ella es tan indiferente a él como la naturaleza misma: que la naturaleza permita la propagación humana no quiere decir que la desee o la necesite. La naturaleza no ama a los hombres; su extinción le afligiría tan poco como la de los dinosaurios. A los únicos que les importa extinguirse es a los seres humanos en tanto racionales, y sólo cuando hacen razonamientos del tipo de los que ella no hace: ¿qué sucedería si todos los hombres hicieran lo que hacen unos pocos?

Pero, entonces, ¿por qué Sade hace hablar tanto a los libertinos y las libertinas, si hablar puede volverse la divulgación, en contra de sus propios intereses, de lo que debería permanecer en secreto? Si lo hiciera para incomodar al lector, que no vive la vida libertina, su meta sería de corto alcance: el lector de otro siglo podría admirarlo precisamente por eso, haciéndole pagar el precio de edulcorar su pensamiento.

Ese lector, cuando lee a Sade desde la admiración, acepta que la vida libertina no puede ser sino el privilegio de unos pocos, los más poderosos, a costa y en contra de los muchos que no tendrían quién reclame por ellos. Si no fuera así, si a la vida libertina se le restara la criminalidad, se la convertiría en un modo de vida al alcance de cualquiera. La celebración del dispositivo de impunidad sólo es escandalosa para la hipocresía ilustrada: en aquel contexto, para tener privilegios, no hacía falta ocultar para qué servían (eso era imaginable para cualquiera), sino con qué recursos era fácil conseguirlos.

Ahora bien: al lector que no parte de la admiración por Sade, ¿qué podría incomodarle de una vida libertina enteramente imaginaria (mucho más, si advierte que está presentada como una ficción teórica), que no sea el requerimiento de impunidad del que ningún poderoso, en la vida extraliteraria, podría hacer alarde sin ponerla en riesgo? (de ahí también que su violencia no pueda ser sino silenciosa).

\section{Sade después de Fogwill}

A un lector actual, que sabe de los campos de concentración por los testimonios de sus sobrevivientes, podría incomodarle (o directamente ofenderlo) tener que aceptar, como un plus de la ruptura de la inverosimilitud, que los que hablan en las novelas de Sade sean personajes que, de existir empíricamente, tendrían que mantenerse callados. Y que tendrían que hacerlo no tanto por conveniencia (por el hecho de que, si dijeran en el mundo empírico lo que dicen en el mundo ficcional, no podrían seguir siendo personas poderosas), sino porque, en el mundo empírico, los poderosos hacen que otros, utilizando la estructura del Estado, se manchen por ellos las manos de sangre.

Así lo da a entender Fogwill, cuando critica, como parte de la herencia semántica del Proceso, que se le llame dictadura militar a lo que fue, en realidad, un proceso de carácter «banquero, oligárquico, multinacional» (2008b:68), aunque se lo haga, justamente, para no usar el nombre que ese proceso se dio a sí mismo (Proceso de Reorganización Nacional). 
Con el término dictadura militar — dice Fogwill en 1984- se oscurece el verdadero carácter de proceso económico que tiene el Proceso, porque se lo llama por el nombre que más le conviene a quienes se ocultan detrás de él: el de los servidores circunstanciales de su política económica.

De todos modos, lo mismo que Bataille sostiene sobre Sade (que si se lo admira se lo edulcora) vale para Fogwill. En el párrafo siguiente al que atribuye a la herencia semántica del Proceso el uso oscurecedor del nombre dictadura militar (2008b:68), dice que, cuando se habla de desaparecidos, «se engloba bajo el mismo signo a quienes murieron en la perplejidad del error - las víctimas inocentes - con las víctimas combatientes, cuya muerte fue a confirmarles la verdad de su caracterización del Estado argentino, independientemente de sus desaciertos en la evaluación de las tácticas y de la lealtad de sus conducciones» (69).

Aunque el mismo Fogwill había aclarado, en 1983, que no era un «recién venido a las letras» - lo que equivalía, en ese momento, a ser «un recién llegado a la izquierda»-, sino un "hace mucho llegado a la derecha» (I07), su tesis sobre la «herencia semántica del Proceso» (al anteponer las razones económicas a las razones políticas de la dictadura) es, para el momento en el que fue enunciada (1984), una tesis de izquierda que la izquierda, por entonces, no podía enunciar, porque la prioridad, cualquiera fuera su vertiente, era la reivindicación de los derechos humanos y el juzgamiento de los represores: aparición con vida / y castigo a los culpables.

En relación con los libros que se publican sobre la dictadura (a los que él llama los libros de la guerra), Fogwill se pregunta con mayor radicalidad que Bataille y ateniéndose a casos concretos, por qué la violencia es silenciosa:

Si se exceptúan Nibilismo y experiencia extrema, de Víctor Massuh, y el curioso volumen colectivo que editó el empresario Piñeiro Pacheco con el título de Pensar la Argentina, en los primeros años del llamado "Proceso" la ofensiva editorial corrió por cuenta del bando perdedor: las organizaciones subversivas y los sectores políticos y culturales que, sin asumir los objetivos o los métodos de la guerrilla, compartían con ella el repudio del terror de Estado. (...) ¿Por qué el bando de los vencedores no tuvo una bibliografía más extensa? Hay dos respuestas: ellos contaban con el consenso público y con la solidaridad de todos los medios de comunicación de masas. (...) El segundo motivo es la dificultad para controlar las consecuencias de los libros. Recuérdense los penosos efectos del libro de Camps (Caso Timerman, Punto final), que mostró la inconveniencia de narrar la historia desde el punto de vista de los circunstanciales vencedores (...) Los registros de la derrota y las evocaciones de las derrotas son parte de un aparato involuntario de celebración de las victorias, especialmente cuando no hay obras de celebración de la victoria porque los victoriosos necesitan hacerla pasar como una derrota. (2008a:82)

Lo que hace hablar a Fogwill de victoriosos y perdedores y no de bárbaros y civilizados —el par de conceptos de Bataille—, para pensar de qué lado queda la palabra y de qué otro el silencio, es su énfasis —un énfasis que lo pone, de 
por sí, a la izquierda de lo que critica - en el poder oscurecedor del léxico progresista: con ese léxico, al que se recurre a partir de 1984 por falta de uno mejor (el de la izquierda revolucionaria está en desuso), no se puede nombrar ni la victoria-derrota de los vencedores (el hecho de que los representantes del poder económico banquero, oligárquico, transnacional, para seguir haciendo negocios en democracia como los hacían bajo la dictadura, tengan que callar su victoria), ni la derrota-victoria de los perdedores (el hecho de que sean ellos los únicos que van a pensar y a narrar el terror de Estado).

El punto de vista de Fogwill sobre la dictadura es tan paradójico como el de Sade sobre la aristocracia: ambos hacen hablar, en sus ficciones, a quienes en la realidad empírica permanecen callados. Pero Fogwill hace que quienes deberían permanecer callados, en tanto representantes (menores) del poder económico (el gerente de una multinacional, como Fernando Romero en Nuestro modo de vida, o un importador de tecnología militar, que fue agente de inteligencia en la dictadura, como Wolff en Vivir afuera), hablen de todo menos de aquello que los hace (medianamente) poderosos. Toda persona poderosa, en tanto personaje fogwilliano, se comporta $-\mathrm{y}$ habla en consecuencia - como intermediario entre poderes que lo exceden. Todos los representantes del poder son, en tanto hablan, intermediarios.

En Nuestro modo de vida (una novela cuya primera versión data de I980 y que permaneció inédita hasta 20I4), Fernando Romero le cuenta a su mujer, Rita, un episodio reciente, que recuerda, repentinamente, a propósito de un accidente de tránsito que los tiene varados en medio de la autopista:

—Yo una vez... ¡Nunca te lo conté! — decía Fernando—. ¿Te acordás aquella vez que me quedé a dormir en la quinta de Esteban, en Tigre...? (...) Esa tarde salimos a esquiar en una lancha y varamos contra algo, cerca del canal Mitre, donde desembocaba antes el Paraná de las Palmas... (...) - Y entonces Víctor creyó que era un camalote, y empezó a forcejear con una caña, o con un remo, y enganchó algo... (...) — Y lo levantó y era un cuerpo humano, atado con cadenas y pedazos de hierro, para impedir que flotara, y una cadena lo unía al fondo, y Esteban y Víctor empezaron a recorrer la cadena con el remo y aparecieron más cuerpos, eran muchos, seis o diez, todos enganchados con cadenas y con fierros, para que flotaran a dos aguas... para que la corriente se los fuera llevando... Esa noche dijimos que no se lo íbamos a contar a nadie. No sé por qué. (...) Cuando llegaron a la calle de los restaurantes habían olvidado el accidente y los recuerdos que el accidente había evocado. (...) Decidieron comer en una taberna escandinava cercana. Como pensaban beber mucho vino, tomaron dos pastillas de Qualine con Tetra K, alguno de cuyos componentes atenuaba los efectos negativos del alcohol. (Fogwill 20r4:82-84)

La misma pastilla de Qualine con Tetra K Fernando la había tomado durante el baño de inmersión, antes de vestirse para salir a cenar afuera, acompanándola con un vaso de jugo de naranja:

Sintió los primeros efectos del Qualine: un leve escozor en los músculos superficiales del cuello, una sensación de saciedad en la garganta, la certeza de que sus miembros estaban 
alertas, dispuestos a obedecer cualquiera de sus deseos pero a la vez relajados y en descanso. El efecto se producía a los pocos minutos de tomar la pastilla y duraba tres o cuatro horas. Por eso temía quedarse sin esas pastillas que permitían superar el agotamiento del día y a la vez promovían sensaciones que, como decía la publicidad, «daban un color más a la vida». La vida era amarilla con una franja diagonal roja ahora: los colores de la cápsula de Qualine con Tetra K que grotescamente reproducía la etiqueta del frasco. Desde esta óptica, vista con los colores de Qualine, el agua caliente era una fuente de placer, el agua fría otra, y el contraste entre el agua fría y el agua caliente era otra distinta pero con idénticos resultados. (76)

Antes de que Rita tome también, para acompañar a Fernando, un Qualine con Tetra $\mathrm{K}$ junto con un vaso de jugo de naranja, y luego de haber tomado ambos un vaso de Coca Cola con una aspirina - como un paso previo a subir al dormitorio, para tener sexo, antes de fumarse, cada uno, un cigarrillo-, ella le dice a su marido que, en ciertos momentos, se siente «dirigida por otros»:

—Por otros... ¿ ¿cuándo? - Hoy, en el desayuno, después, cuando charlamos en el living... y ahora, aquí. (...) —No sé, me siento a la vez como mirada y como si alguien nos dirigiera... — ¿Y te pasó antes...? —Sí, alguna vez, pero ahora, cuando estoy con vos, siento eso, siento que alguien nos dirige a los dos. —Puede ser... siempre alguien te dirige... (7I-72)

Rita y Fernando hablan en la ficción, estando solos, como hablarían en la realidad empírica bajo un estado paranoico: aun estando solos, se sienten mirados, es decir, oídos. Sobre lo que incluso entre ellos no pueden hablar no sólo deben callar: también deben, para no hablarlo, omitirlo de sus pensamientos.

Cuando durante la espera en la autopista por el accidente de tránsito, Rita se pone nerviosa, Fernando lo advierte y le pregunta si es por la espera de cuarenta minutos o por tener que presenciar, aunque sea a distancia, el traslado de los cadáveres de las víctimas. Rita le responde contándole un sueño:

-Yo una vez (...) soñé que sufría un accidente parecido. No sé cómo ocurrió. Lo cierto es que papá y mamá, que iban en el asiento delantero, se reventaban contra el parabrisas del auto. Era un auto grande y primero se reventaban las caras y las cabezas, y yo veía los sesos saliendo, como si fuesen intestinos, y recién después se rompía, estallaba en añicos, el parabrisas (...) y entonces yo pensaba que no iba a poder vivir con esa imagen, y como si fuese cámara lenta, el auto se partía, y yo y todos mis hermanos, que íbamos en el asiento trasero, nos reventábamos contra el techo del auto que volcaba en cámara lenta, y nos moríamos. Y estaba muerta, y me desperté, y ahora vivo con esa imagen, y es como si yo también me hubiera muerto. (8I-82)

La narración del sueńo de su propia muerte, por parte de Rita, dispara en Fernando (como si se tratara de una memoria fotográfica, que asocia entre sí imágenes congeladas), el recuerdo de ese día en el Tigre, en el que practicando esquí acuático choca contra lo que cree un camalote y resulta ser, sin que el hecho lo sorprenda o 
lo horrorice, un cadáver encadenado a otros cadáveres encadenados. Que esa noche, en el Tigre, Fernando y sus amigos decidan no contarle a nadie el episodio los pone en la posición de quienes saben que deben callar. Fogwill, por eso, no lo hace hablar a Fernando, ni siquiera frente a su mujer, de lo que sabe que debe callar. Los vencedores callan. Los que quedan de su lado, también. Pero para callar - demuestran los protagonistas de Nuestro modo de vida - tampoco hay que pensar en aquello que se calla. Los que piensan o narran - actividades que Fogwill presenta como equivalentes y como asociadas a la derrota - son los perdedores.

Lo que Fernando calla, Rita lo sueńa. La conclusión que ella saca de su sueño es que ya está muerta: es una muerta viva, una zombie, una descerebrada, alguien que no piensa, alguien cuyos movimientos siente dirigidos (y observados) «por otros».

Así y todo, Rita no está aterrorizada por haber quedado del lado de los vencedores (los verdugos de los que los vencedores se sirven - debe suponer- no podrían tirarla al río), pero se siente dirigida (y observada) por ellos.

La violencia silenciosa, en el caso de Nuestro modo de vida, no puede ser tomada como la violencia ajena, la violencia de los otros, porque los otros - los que encadenaron los cuerpos y los tiraron al río - no son bárbaros —en la terminología de Bataille-, aunque se valgan de verdugos barbarizados, sino vencedores —en la terminología de Fogwill— que, como tales, cuando la etapa barbarizada cese, tendrán que ocultar su victoria.

En Vivir afuera, Wolff — un ex agente de inteligencia de la dictadura que en el presente de la acción, 1997, se ha reciclado como importador de tecnología para las fuerzas de seguridad - no puede recordar de ciertos años de su vida sino aquello que se repite y, en tanto repetido, le resulta intrascendente:

Cuando despidió a su último acompañante y cruzaba la avenida Santa Fe tenía la sensación de haber visto más de una vez esas mismas escenas. ¿Cuándo?

Trataba de recordar y en su memoria se confundían distintas imágenes nocturnas e invernales: el año sesenta y ocho, el año setenta y tres, el setenta y siete, el ochenta y cinco: siempre hubo épocas disponibles para situar estas apariencias de patetismo nocturno e invernal. Razonablemente podía calcular que nunca había asistido a escenas como éstas: latinoamericanizadas, televisadas, supervisadas desde el cielo. Pero sentía que sí, que ya lo había visto y que quizá estuviese escrito en alguna parte y que podría encontrarlo si valiera la pena revisar sus papeles. La sensación de llevar un agujero creciendo en la memoria volvía a acentuarse a medida que se acercaba a la cochera de su edificio: era un vacío de años, hecho de tiempo discontinuo. No eran diez años: eran bloques de semanas y meses marcados por algo que unas imágenes invernales, en pleno mes de noviembre, representaban con exactitud.

Pensó que cuando se librase del 505 y estuviera frente a su escritorio, con la calefacción encendida, una taza de mate cocido, una pastilla estimulante, tal vez un cigarrillo y un encendedor desafiando su voluntad, a la vista de su agenda con los planes de la semana y, entre sus páginas, el cheque que le acababan de traer de Paraguay, conseguiría definir por fin el significado de esa sensación que insistía en escapársele. (1998:55-56) 
En la mente de aquel que no recuerda - imagina el narrador omnisciente de Vivir afuera - domina la indistinción. Todo se termina pareciendo, la calle Santa $\mathrm{Fe}$, la avenida Libertador, los edificios de Coronel Díaz, las noches y los días. No obstante, la industria automotriz y la industria de los perfumes avanzan a otro ritmo que las sociedades que los consumen (la industria de los perfumes a un ritmo exponencialmente más vertiginoso que la de los automóviles):

Recordando parece todo igual, pensaba Wolff, mientras comparaba el final de esa mañana de 1997 con cualquiera de las escenas de los años setenta que, de tan iguales, se confundían en su memoria. Si no se miran los edificios de Coronel Díaz, sólo el autito y olor de las dos minas de atrás muestran que, efectivamente, pasaron los años. Este es un Fiat que habrán diseñado en Italia a comienzos de los ochenta, pero no difiere en mucho de lo que en el setenta y tres pudo ser un auto de vanguardia tecnológica: un nuevo modelo de la Renault o la Citröen o una actualización de Volkswagen especialmente creada para el mercado asiático y el mundo socialista. Los perfumes, en cambio, desconcertarían a cualquier empleada de Pozzi de aquellos tiempos. (377)

Del mismo modo que la industria perfumística avanza a un ritmo que desconcierta a las propias sociedades que consumen sus productos, la formas del espionaje se tecnifican en un sentido que va del lenguaje escrito, propio de los informes burocráticos, al lenguaje de las imágenes digitales, propio de las pantallas de computadora.

Cuando hacia el final de Vivir afuera (a partir de la página 374) se produce un giro en el punto de vista (porque el narrador omnisciente cede su lugar, repentinamente, a los informes de los espías que cada personaje tiene asignado), la omnisciencia (un atributo divino) es reemplazada, en las páginas siguientes, por la unilateralidad de la perspectiva del informante. Sin embargo, como los informantes adoptan, en cada caso, el léxico aséptico de los informes burocrático-científicos, la narración se identifica, en su frialdad deshumanizada, con el punto de vista del Estado:

Observadas desde la ventana del office de Neurocirugía, (...) una de las mujeres debía ser practicante o enfermera del hospital, vestía guardapolvo, pero con ruedo corto, por encima de las rodillas. (...) Viéndolos desde el interior de la vivienda de la familia Ibañes, «Pichi» no parecía preocupado por la seguridad de la motocicleta que a las I2.30 abandonó en la vereda de tierra sin adoptar medida de seguridad alguna. (...) A las I2.5O se hizo presente la mujer conocida como la «Peti» portando una mochila y vestida con jeans, suéter, campera y botas de cuero, siendo su aspecto general de pulcritud (...) La pareja se despidió de la mujer besándola ambos como si fuesen familiares cercanos. No se verificó que la chica dejara parte del contenido de su mochila en su poder y consta que en momento alguno se apartó de la compañía de la señora Pilar al tiempo que a ninguna de ambas se vio ingresar al interior de la vivienda. (...) Visto así, desde el puesto del chofer, deformado por el espejo convexo que facilita el control del interior de la unidad, nada del aspecto ni del comportamiento del pasajero permite 
confirmar que se trata de un sacerdote. (...) Durante la media hora de viaje sobre la autopista no se distrajo de la lectura de un diario, Página I2, del día de la fecha (...) No se detectaron indicios de que al arribo alguien haya hecho contacto con el objetivo (...) Se dirigió a pie hacia la estación ferroviaria, quedando al cabo de unos minutos fuera del alcance del personal que rindió cuenta de la presente continuidad de información. (374-377)

Pero el punto de vista de la vigilancia burocrático-estatal, una vez terminados los informes de los informantes, vira al punto de vista de otro tipo de vigilancia: el control burocrático-privado del consumo, que se realiza a través de cámaras.

El narrador, a partir de ese momento, deja de identificarse con la lengua burocrático-jurídica de los informes escritos (y escritos para ser archivados), propia de la observación policial de conductas presuntamente sospechosas, para pasar a incursionar, de ahí en más, en el comentario sociológico de tono coloquial, dirigido a conductas presuntamente intrascendentes pero que refieren, para un ojo entrenado, a hábitos de consumo perfectamente clasificables:

A ningún cliente del shopping, que por un momento se distrajera observando a estos cuatro que desembarcan del ascensor y parecen venir del estacionamiento del subsuelo, le llamaría la atención el grupo (...) Pero un personal entrenado y con meses de experiencia en la observación del flujo de público, ante un grupo de adultos tan desparejo en edad, sin señales ni muchas posibilidades de guardar parentesco entre sí, sólo puede suponer que son el frecuente conjunto de compañeros de oficina que sin mirar ni comprar se dirige directamente a los patios de comida para hacer un almuerzo rápido. Pero ninguno de ellos, ni las mujeres ni los hombres, parecen gente de oficina. (...) Los hombres son el típico cliente que estaciona un 504 y se retira a la media hora, sin comprar ni revisar nada. Raros, pero no misteriosos. Se volverían misteriosos si ahora apareciesen bajando por las escaleras mecánicas, pero con la ropa cambiada: el viejo con el saco sport gris de Chemea y los zapatos de punta levantada del otro y el más joven con el mismo pantalón de sarga barata pero con los mocasines náuticos del mayor. O que aparezcan ellas con los pelos cambiados: la negrita de ojos grandes teñida del color natural de la otra y la castaño clara con el pelo colorado y brilloso de la otra que tiene jeans de gabardina de seda y campera de Cahen D'Anvers. (378-379)

La siguiente - y última - mutación del punto de vista, en Vivir afuera, es el pasaje, en tono distendido y jocoso, al análisis de datos informáticos (antes de que la narración retorne, primero, al punto de vista del informante policial, y finalmente, en el desenlace, a su posición estándar, mantenida hasta la página 374, de total omnisciencia).

El análisis de datos, en el caso del shopping, se vuelve más claro cuando pasa de las cifras económicas a las imágenes a las que esas cifras quedan traducidas:

Siguiendo día a día la curva del rubro Varios, sea la representación real, en amarillo, o la desestacionalizada, que está en azul, vas a ver que las ventas no marcan cambios mes a mes, ni año a año, salvo la media estacional. (...) Menos se vende, más pesa el rubro Comidas en el 
total de ventas (...) Lo más estable es el flujo: flujo bruto de gente y flujo neto de operaciones, corren siempre parejo y si ves algo raro es porque es miércoles y cuesta menos la entrada. (...) $\mathrm{Si}$ entraron a la hora del cine, todos terminan pagando aunque sea el valor de la entrada. Si querés una imagen más gráfica, pedí que te lleven a conocer la consola. Los consoladores, los pibes que están ahí mirando las pantallas, la tienen más clara que los de análisis de marketing. No les pidas cifras: ni idea tienen de cifras. (38I-382)

El mismo principio —el de la clarividencia de la imagen — se aplica al análisis del historial de internet del personaje de Saúl, un médico de hospital público especializado en el virus del HIv:

No pasa un día sin que entre en la página de Duesberg. Imprimimos un índice para que alguien que sepa de biología la clasifique (...) porque es una de las páginas que figura como objetivo en los trackings americanos y si los gringos sospechan, por algo será. O el Infoseek o los mismos tipos que publican la página en Berkeley destacan las palabras clave Drugs, CIA, State Department, War. Drogas, cia, o sea, Departamento de Estado, Guerra, Guerra Bacteriológica. (...) También mira los diarios de Israel en esta PC, cada tanto lee Clarín y el New York Times y como todos los médicos es un pajero: no pasa semana sin que navegue por uno o dos sitios porno, siempre los mismos. (...) Si la red estuviese bien instalada, se podría recuperar todo lo que borró, pero esta es una red de hospital, pensada para esta clase de gente que viene a trabajar un ratito y le importa un carajo lo que puedan necesitar las autoridades. (383-384)

Al punto de vista omnisciente de Vivir afuera, durante ciertos intervalos cercanos al desenlace, lo reemplaza un punto de vista unilateral, sesgado, restringido a la exterioridad de las conductas, propio de aquel que espía desde un dispositivo de poder (estatal, paraestatal, comercial, informático) sin ser, por eso, un personaje insertado en la trama, con el que el resto de los personajes tienen trato o diálogo. Este punto de vista, el de una mirada que no pertenece a un personaje pero que está presente dentro de la acción, imita al de una cámara.

La frialdad de ese punto de vista unilateral, que mira sin involucrarse con lo mirado, no es sadiana: no es la frialdad de la medicina en la época en que se descubre la anestesia, es decir, una frialdad de la ciencia aplicada, propia del siglo XVIII. Esa frialdad es postsadiana, una frialdad tecnológica — ni siquiera tecnocientífica - propia de la época de la cámara, no de la era del microscopio.

En el hecho mismo de que Bataille diga, en la década de I950, que no va a adoptar frente a Sade el punto de vista de sus admiradores (porque, si lo adoptara, lo edulcoraría), hace pensar hasta qué punto sus potenciales lectores (los de Bataille y los de Sade al mismo tiempo) son contemporáneos de un giro estético en relación con la violencia silenciosa.

Ese giro lo realiza la mirada, tal como advierte Hitchcock cuando filma Psicosis en 1960, en blanco y negro en lugar de en colores, y hace que el film no sólo cambie de protagonista en la mitad de su metraje sino que el lugar de la heroína muerta lo ocupe su asesino. El espectador aprende allí no tanto que en una mis- 
ma película puede identificarse primero con la víctima y después con el victimario, sino que siempre se identifica con la cámara.

Así como Eurípides - según Nietzsche - mata la tragedia al subir a la plebe al escenario, Hitchcock hace lo mismo con el cine clásico, al introducir la mirada del espectador en sus películas. El espectador al que se dirige Psicosis es un espectador soberano, que puede ver la violencia silenciosa tanto desde el lugar del verdugo como desde el lugar de la víctima, sin identificarse con ninguno de los dos roles (de ahí la frialdad extrema de su mirada).

La lengua de Fogwill, igual que la de Sade, no se identifica con el lenguaje que los verdugos hablan entre sí y que es la lengua que los justifica, la lengua del Estado. Fogwill escribe desde un saber extraliterario que no ha conseguido dentro del Estado sino fuera de él: su punto de vista frente a la dictadura, como punto de vista extramoral, es el de alguien que ha trabajado, por su experticia como publicitario, haciendo ganar dinero a las empresas de los poderosos (que formaron parte —o apoyaron - el proceso banquero, oligárquico, multinacional que el Pueblo argentino prefiere llamar dictadura).

Pero cuando Fogwill escribe ficción, en lugar de identificarse con sus clientes que callan — como Fernando Romero en Nuestro modo de vida_, se dirige a un público al que, cuando escribe como sociólogo, califica, despectivamente, de progresista (y que es el público que lee las revistas que publican sus artículos: $E l$ Porteño, Primera Plana). Sólo que, al dirigirse a ese público, se pone, inevitablemente, del lado de los perdedores, porque, en su papel de ilustrado oscuro, lo esclarece sobre cómo debería hablar, si no quiere seguir perdiendo, de los verdaderos vencedores.

El uso consecuente de la razón, que sólo pueden hacer, sin temer sus consecuencias, las personas poderosas, Fogwill se lo enseńa, para que aprendan a usarlo en su favor, a los perdedores, aclarándoles, como si fuera poco, que los victoriosos no necesitan pensar ni narrar. Y que por eso callan. Pero al tener que callar, su victoria no puede ser celebrada.

\section{Bibliografía}

Arendt, Нannah (195I). Los orígenes del totalitarismo. Madrid: Taurus, 1974

Bataille, Georges (1957). El erotismo. Buenos Aires: Tusquets, 2009

(1988). «El soberano». La felicidad, el erotismo y la literatura. Ensayos 1944-I96r.

Buenos Aires: Adriana Hidalgo, 2008, 227-244

Fogwill, Rodolfo Enrique (1998). Vivir afuera. Buenos Aires: El Ateneo, 2012

(2008a). «La guerra sucia: un negocio limpio de la industria editorial (El Porteño, agosto 1984)». Los libros de la guerra. Buenos Aires: Mansalva, 20I0, 82-91.

(2008b). «La herencia semántica del Proceso (Primera Plana, abril 1984)». Los

libros de la guerra. Buenos Aires: Mansalva, 2010, 68-69.

(2014). Nuestro modo de vida. Buenos Aires: Alfaguara. 
Horkheimer, Max (1936). «Egoismus und Freiheitsbewegung». Kritische Theorie. Band 2. Frankfurt/M: Fischer, I968, I-8I.

Horkheimer, Max y Theodor W. Adorno (1947). «Excurso II: Juliette o iluminismo y moral». Dialéctica del iluminismo. Buenos Aires: Sudamericana, 1987, I02-I45.

Le Brun, Annie (2006). No se encadena a los volcanes. Buenos Aires: Argonauta, 2011.

Nietzsche, Friedrich (I889). El Anticristo. Maldición sobre el cristianismo. Madrid: Alianza, I99I.

SADE, Marqués de (1797). Juliette. Tomo I.Madrid: Espiral: 1987. 